\title{
Securitization on the Spread of COVID-19 in Indonesia \\ Sekuritasasi dalam Penyebaran COVID-19 di Indonesia
}

\section{Cornelia Clara Tifany}

Faculty Of Social Science And Political Science, Universitas Sebelas Maret

email: corneliaclaratifanysantoso@yahoo.com

\begin{tabular}{l}
\hline Riwayat Artikel \\
\hline Diterima: 14 April 2020 \\
Direvisi: 5 Oktober 2020 \\
Disetujui: 7 Oktober 2020 \\
doi: $10.22212 /$ jp.v11i2.1749
\end{tabular}

\begin{abstract}
Based on the World Health Organization report, Coronavirus disease 2019 (COVID-19) is an infectious respiratory disease that has become an epidemic in approximately 213 countries throughout the world, including Indonesia. Prior to the first confirmed case of COVID-19 in Indonesia, the Indonesian government's response, as represented by its high-level officials, suggested a lack of awareness. Some situations then became the turning points for the Indonesian Government, who has since focused more on dealing with the COVID-19 outbreak. Through this research, the writer aims to analyze the Indonesian Government's treatment of COVID-19 from a health issue to a security issue. Therefore, the securitization theory focusing on the component of securitization from Buzan will be employed as an analytical framework in this research. In addition, the global health governance is also used as a reference to support the writer's statement. In order to explain the action of the Indonesian Government, this research will use qualitative research with a focus on literacy observations through online news relating to the issues. In conclusion, the change in action of the Indonesian Government was caused by the pressure from GHG, which then showed that the spread of COVID-19 in Indonesia is a security issue.

Keywords: COVID-19; Health Issue; Security Issue; Securitization; Global Health Governance.
\end{abstract}

\begin{tabular}{l} 
Abstrak \\
\hline Coronavirus disease (COVID-19) yang merupakan penyakit pernapasan \\
menular telah mewabah kurang lebih di 213 negara di dunia berdasarkan \\
pada laporan World Health Organization, salah satu negara yang terkena \\
wabah adalah Indonesia. Sebelum ada konfirmasi atas kasus COVID-19 \\
di Indonesia, terlihat sikap pihak pemerintah yang diwakili oleh pejabat \\
tinggi menunjukkan sikap kurang perhatian. Namun beberapa situasi \\
menjadi "turning point" bagi Pemerintah Indonesia yang kemudian \\
memberikan fokus yang lebih dalam menghadapi wabah COVID-19 \\
di Indonesia. Dari keadaan tersebut melalui penelitian ini, penulis \\
menganalisis sikap Pemerintah Indonesia dalam mengubah isu kesehatan \\
menjadi isu keamanan. Penelitian ini menggunakan teori sekuritisasi \\
sebagai kerangka analisis dengan terfokus pada komponen sekuritisasi \\
oleh Buzan. Di samping itu juga menggunakan tata kelola kesehatan \\
global sebagai penopang pernyataan penulis. Agar mampu menjelaskan \\
sikap Pemerintah Indonesia maka penelitian ini menggunakan metode \\
penelitian kualitatif dengan fokus pada pengamatan literasi melalui \\
berita daring yang berkaitan dengan permasalahan yang diangkat. Dalam \\
kesimpulannya, perubahan sikap Pemerintah Indonesia disebabkan oleh \\
adanya tekanan dari tata kelola kesehatan global yang menunjukkan \\
bahwa penyebaran COVID-19 di Indonesia merupakan isu keamanan. \\
Kata kunci: COVID-19; Isu kesehatan; Isu Keamanan; Sekuritisasi; Tata \\
Kelola Kesehatan Global.
\end{tabular}




\section{Introduction}

COVID-19 is an infectious disease through drops of saliva or water drops that come out of the nose when someone who has been infected with the COVID-19 virus coughs or sneezes. This form of infection COVID-19, most people will experience respiratory disease on a mild to moderate scale. That newly discovered virus has not yet been found a vaccine or special treatment, therefore infected people are likely to recover without requiring special care. ${ }^{1} \mathrm{WHO}$ has confirmed as many as more than 23 million cases with a mortality rate reaching more than 800 thousand dated 23 August 2020.2

It is easy to transmit COVID-19 through droplets of saliva or water droplets that come out of the nose of an infected person, WHO advises the public to reduce the level of transmission. These recommendations include washingyour hands using an antiseptic (alcoholic based) or soap frequently, at least one meter away from other people, avoiding crowds, and avoiding touching around the face, especially avoiding touching the eyes, nose and mouth. Some of these things must be able to be done by the community so that there is no increase in the number of people who are infected with COVID-19. Apart from these things, WHO also recommends the habit of covering the mouth and nose using the folds of the elbows or using a tissue then immediately throwing away the used tissue and washing hands. WHO also advised to stay at home, remembering that doing so would help to break the chain of spread of COVID-19. In addition, WHO has also been intensively using masks when outside

1 World Health Organization, "Coronavirus", retrieved 9 April 2020, https://www.who.int/healthtopics/coronavirus\#tab=tab_1

2 World Health Organization, "Coronavirus disease (COVID-19) Pandemic", retrieved 9 April 2020, https://www.who.int/emergencies/diseases/novelcoronavirus-2019 the home. ${ }^{3}$ Various recommendations have been given by WHO to reduce the level of COVID-19 spread, which is the basis for every country in the world which is then implemented by each local government so that these recommendations reach every community.

COVID-19 began on December 31, 2019, the Government of Wuhan, China confirmed that there were many cases of pneumonia being treated for which the cause of the outbreak was not known. When investigated further, the Wuhan Government said it had not found a virus that could easily spread to humans. Then the COVID-19 case was first confirmed by the Government of Wuhan, China. Case finding began with an outbreak of a disease that infected dozens of people, which was then identified as a new type of virus. The first case of death in Wuhan, China was confirmed on January 11,2020, which is a 61-year-old male who is a regular customer in the Wuhan market. Then the spread occurred until January 20, there were confirmed cases outside of China, such as in Japan, South Korea and Thailand. As the number of infected has increased, the Chinese Government has closed all types of transportation in Wuhan, both transportation to Wuhan or out of Wuhan. ${ }^{4}$ Until March 2, 2020, Indonesia through President Joko Widodo confirmed 2 COVID-19 cases in Indonesia. ${ }^{5}$

3 World Health Organization, "Advice for the public", retrieved 23 August 2020, https://www.who.int/ emergencies/diseases/novel-coronavirus-2019/ advice-for-public

4 Taylor Derrick Bryson, "A Timeline of the Coronavirus Pandemic”, New York Times, 7 April 2020, retrieved 9 April 2020, https://www.nytimes.com/article/ coronavirus-timeline.html

5 Gorbiano Marchio Irfan, "Indonesia's first two confirmed COVID-19 cases", The Jakarta Post 2 March 2020, retrieved 9 April 2020, https://www. thejakartapost.com/news/2020/03/02/breakingjokowi-announces-indonesias-first-two-confirmedCOVID-19-cases.html 
The first COVID-19 case in Indonesia began with one that was confirmed to have contact with a Japanese citizen on February 14, 2020. Then one of them made contact with one of her family, this led to the next COVID-19 case. It is known that the Japanese citizen who lived in Malaysia underwent an examination in Malaysia, where the result was positive for COVID-19. This information was obtained by two citizens of the country who were confirmed cases, who then both underwent an examination at the hospital and tested positive for COVID-19. From this initial case, the Indonesian government carried out tracing by knowing the activities of them. ${ }^{6}$ This was done to determine the transmission of COVID-19, which is expected to reduce the possibility of a wider spread of COVID-19.

Before Indonesia confirmed the discovery of the COVID-19 case, Indonesia, through high officials, showed the impression of not paying attention. This is because when other countries have confirmed cases of COVID-19, Indonesia has not found any confirmed cases, which forms a belief that Indonesia will feel safe from the spread of COVID-19. It can also be said that there are several statements from high-ranking officials that point to the opinion that COVID-19 is not a serious case even though on the other hand there are statements stating that Indonesia is ready to handle COVID-19. With the statement that Indonesia has prepared a number of actions in dealing with the spread of COVID-19, leading to a growing opinion that the Indonesian people do not need to worry too

6 Kompas, "Kronologi dan Urutan Munculnya 6 Orang Positif Virus Corona di Indonesia", Kompas, 9 March 2020, retrieved 23 August 2020, https://nasional. kompas.com/read/2020/03/09/05280011/kronologidan-urutan-munculnya-6-orang-positif-viruscorona-di-indonesia?page $=$ all much, but on the other hand, several highranking officials also advised the Indonesian people to remain vigilant about COVID-19.

Actions that can be said are actions that seem to pay less attention to the spread of COVID-19 such as the government which ensures that COVID-19 will not infect the Indonesian people, but this statement is accompanied by another statement from the government about the jokes of highranking officials regarding COVID-19. It can be said that the government was not fully able to show seriousness in dealing with the spread of COVID-19 before confirming the COVID-19 case. This will have a bad impact on the people of Indonesia who are worried about the spread of COVID-19, which can be said that they are the ones who will be threatened by the spread of COVID-19. However, there is a change in action from the Indonesian Government which is shown in a statement delivered by the government after the World Health Organization asked Indonesia to establish an emergency response to the spread of COVID-19 which has started to infect the Indonesian people. In other words, WHO has contributed to the changes shown by the Indonesian Government in responding to the spread of COVID-19 by focusing on its spread in Indonesia. The initial change was shown by the issuance of Presidential Decree number 7 of 2020 concerning Gugus Tugas Percepatan Penanganan COVID-19.? With the initial changes - and followed by other changes - it shows that the government has paid more attention to the spread of COVID-19 in Indonesia.

7 CNN Indonesia, "Ditanya WHO Soal Tanggap Darurat, Jokowi Jawab dengan Keppres", CNN Indonesia, 14 March 2020, retrieved 9 April 2020, https://www.cnnindonesia.com/nasion al/20200314080137-20-483342/ditanya-who-soaltanggap-darurat-jokowi-jawab-dengan-keppres 
Seen from the change of actions taken by the Indonesian Government in dealing with the spread of COVID-19 raises several questions. These questions are "What is the point of view of the Indonesian government on the spread of covid-19 as a security issue that threatens the existence of a country?" and "What is the role of WHO as global governance on the spread of covid-19 in Indonesia?".

\section{Purpose of Research}

This research has the aim to find out the response from the Indonesian Government on the spread of COVID-19 in Indonesia. From this response, it will be seen that the Indonesian Government positions the issue of spread of COVID-19 as a security issue. Apart from looking at the response of the Indonesian Government, this research will also look at the role of WHO as global governance by focusing on the influence of $\mathrm{WHO}$ in the spread of COVID-19 in Indonesia.

\section{Methodology}

The methodology used in this paper is qualitative research with a focus on literacy observations. The use of this type of qualitative research in this research is because the analysis used is a social problem that is related to policies issued by a country. Meanwhile, the literacy used will focus on online news relating to the actions of the Indonesian Government in the spread of covid-19. The collection of literacy is used to understand how the Indonesian Government responds to the spread of covid-19 in Indonesia. Observations will be supported by an understanding of several theories such as securitization and global health governance. The use of some of these theories will be useful in explaining writing analysis to satisfy the objectives of the research.

\section{Theoretical Framework}

This study uses several theories to analyze problems in order to be able to explain theoretically. The main theory that underpins the analysis in this study is securitization theory which is used as a framework analysis. Considering that the security issue does not only cover issues concerning militarization but has expanded to other issues, one of which is a health issue that can be seen as a security issue. Securitization itself is interpreted as a social construction in the form of norms which are dynamic in accordance with the agreement of the parties involved. It can be said that the determination of an issue into a security issue is an intersubjective process in which there is politicization in its determination which can affect the government and / or the society. ${ }^{8}$

In securitization there are several components that must be considered in order to analyze an issue that is seen as a security issue. The first component relates to securitizing actors who play a role in declaring something that is existentially threatened. Securitizing actors include the government represented by high-level officials, lobbyists, and even pressure from a group. The other component is related to the party who becomes the reference for the security established -referred to as referent objects. The next important component is the action taken by securitizing actors, namely the speech act. Securitizing actors use speech acts as a means of defining an issue classified as a security issue. The last component is the audience which is the target of the speech act by securitizing actors. Audience in this case provides a justification for the actions of securitizing

8 Barry Buzan, Ole Wæver, Jaap de Wilde, A New Framework For Analysis (London: Lynne Rienner Publisher), 1998, 29-31. 
actors who then gives approval to the decision makers. Through these four components, an issue can be identified in a securitization situation. ${ }^{9}$

Another theory used in this research regarding global governance. David Held explained the international situation with many actors giving rise to many interests where these interests conflict with one another. Therefore we need a multipolarity, it is due to the inability of the actors which in this case is the state in solving problems and it is difficult to achieve effective resolutions for all parties. The situation raises concerns over the formation of a global governance which will explicitly give privileges to rich countries. But on the other hand, it is also needed to secure participation from countries that are classified as important or countries that have influence in global governance. Global governance itself is a set of norms and rules that are created to manage the politics of each country in interacting with each other and managing other entities such as multilateral organizations, civil society, and other stakeholders on a global level. ${ }^{10}$ In this research, we will focus on the health dimension, which will focus on the implementation of global health governance. GHG was explained by Sophie Harman that cross-border agreements or initiatives between joint countries and/or non-state actors were used as a reference to control public health and infectious diseases as well as the protection provided to the public from risks or even threats to health. ${ }^{11}$

9 Barry Buzan, Ole Wæver, Jaap de Wilde, A New Framework For Analysis (London: Lynne Rienner Publisher), 1998, 35-47.

10 David Held, "Elements of A Theory Of Global Governance," SAGE Journals Volume 42 Issue 9 (November 2016): 837-846.

11 Kelley Lee and Adam Kamradt-Scott, "The multiple meanings of global health governance: a call for conceptual clarity," Global Health 10 (April 2014): 28.

\section{Securitization}

Previously, it was explained in the theoretical framework related to the use of securitization theory by Barry Buzan in analyzing the spread of COVID-19 as an analysis framework, as well as explaining WHO as GHG in the spread of COVID-19 in Indonesia.

Following are the components of securitization in the spread of COVID-19 in Indonesia:

\section{Securitizing Actors}

There is a component that needs to be seen as a party that provides a claim that there is a threatening situation in an effort to see an issue as a security issue. In addition to providing a claim for a situation that can be threatening, this component also makes a policy that can be said as an action in overcoming that threatening situation. Policy is an effort to convince other components so that a justification for circumstances that can threaten can be formed. This component is securitizing actors which will focus on the actors involved in trying to see an issue.

In dealing with the spread of COVID-19 in Indonesia, there are several parties that can be identified as securitizing actors. These parties are representatives of the Indonesian Government, such as highlevel officials. The Indonesian government in this situation has the role of an actor to frame COVID-19 which is a health issue as a security issue. This role can be seen from the actions taken in responding to handling the spread of COVID-19.

Several high-level officials at the Indonesian Government were identified as securitizing actors in response to handling spread of COVID-19. Securitizing actors will be focused on the President and Vice President of the Republic of Indonesia; 
member of the People's Legislative Assembly; Minister of Health; The Coordinating Minister for Political, Legal and Security Affairs ; Coordinating Minister for Maritime Affairs; Minister of Transportation; up to the Minister of Home Affairs. Some of these actors are identified as securitizing actors based on their authority to act on the spread of COVID-19. The authority is seen from the action on giving claims related to the spread of COVID-19. The claim will show the steps taken by the government in the framing spread of COVID-19 as an issue.

\section{Referent Objects}

The referent object component sees the party that will be affected by the claims of securitizing actors that something is threatening. This component is also the party referred to the policy made for handling threats. It can be said that referent objects are something that is constructed from all actions of securitizing actors.

The referent objects component in the spread of COVID-19 is focused on Indonesian society whether they have been infected with COVID-19 or not. It is seen from the issues raised are health issues which according to the identification of B. Buzan are included in the environmental sector. Its identification in the environmental sector is based on the impact of the spread of COVID-19 on Indonesian society, namely the population problem. It can be said that Indonesian society is directly affected by the threat of population. Therefore in securitizing actors refer to Indonesian society as referent objects in the spread of COVID-19 problem.

\section{Speech Act}

Speech act is the most important component because through this component you will see how securitizing actors are framing an issue as security issue. Securitizing actors use speech acts to form a justification that is intended for other components. In this spread of COVID-19, it can be said that the speech act of securitizing actors constructs the issue as a security issue. The following is the speech act exposure from securitizing actors that shows responses from Indonesian Government

The Indonesian Government has responded to the spread of COVID-19 in the world before the case is confirmed in Indonesia. A statement from President Joko Widodo regarding the spread of COVID-19 was a concern for Indonesian people who were concerned about the spread of COVID-19 in the world. The following statement

"Several countries in the Southeast Asian region have confirmed the entry of the corona virus. However, so far, there has been no indication of the spread of the virus in Indonesia." ${ }^{12}$

From that statement, it is known that the response given by the government regarding the spread of COVID-19 is only to notify the public because there have not been any cases of COVID-19 in Indonesia. The statement from President Joko Widodo can not be identified as a statement directing the issue of the spread of COVID-19 as a health issue or security issue.

In addition to these statements, there are other statements made by members of Commission IX the People's Legislative Assembly, Ribka Tjiptaning, as follows;

"That was explained by the pulmonologist on Metro TV, if I'm not mistaken. This is more dangerous to MERS and SARS than corona, unless the charm of 'rondo' (widow)

12 Pebriansyah Ariefana, "Jokowi Pastikan Indonesia Aman dari Corona", Suara.com, 27 January 2020, retrieved 8 April 2020, https://www.suara. com/news/2020/01/27/123913/jokowi-pastikanindonesia-aman-dari-virus-corona 
community. The danger is that populations of the coronas, be careful, right?"13

The statement can be interpreted as a construction built by the government related to COVID-19 which is not as dangerous as the plague that has struck in the previous world. It can be said as a construction built by the government because the statement was made by one of the high-level officials which is a representation of the government. Therefore it can be said that the construction built by the government does not direct the spread of COVID-19 as a security issue but the issue is only a health issue.

Another statement was also conveyed from the Minister of Health which can be said to be an important actor in the distribution of COVID-19. The statement as follows;

"Let them (Singapore) check, wait for them to make a report, a detailed report on what actually happened, then we can follow up. If we are a bit reactive, our energy will run out." 14

The statement can be interpreted that handling by the government is less serious. That is because the government places the issue of the spread of COVID-19 as a health issue.

Similar to the statements before which positioned the spread of COVID-19 as a health issue, the statements made by several high-level officials also showed the same thing. As a statement from The

13 Rolando Fransiscus Sihombing, "Rapat di DPR, Ribka Tjiptaning Bercanda Korona 'Komonitas Rondo Mempesono", Detik.com, 3 February 2020, retrieved 8 April 2020, https://news.detik.com/ berita/d-4883599/rapat-di-dpr-ribka-tjiptaningbercanda-korona-komunitas-rondo-mempesona

14 Hadi Maulana, "Menkes Terawan: 1 WNI Terpapar Virus Corona, Biar Pemerintah Singapura yang Menanganinya", Kompas, 5 February 2020, retrieved 8 April 2020, https://regional.kompas.com/ $\mathrm{read} / 2020 / 02 / 05 / 20124591 /$ menkes-terawan-1-wniterpapar-virus-corona-biar-pemerintah-singapurayang
Coordinating Minister for Political, Legal and Security Affairs, as follows;

"What I want to say is that until now Indonesia is the only big country in Asia that has no corona cases. The corona virus does not exist in Indonesia" 15

The same statement was also made by the Coordinating Minister for Maritime and Investment, as follows;

"(Corona entered Batam?) Hah? Corona car?" 16

It has been said before that the Minister of Health is the most important actor in the case of the spread of COVID-19 which is very reasonable if the statement from the Minister of Health is used as a benchmark in the issue of spread of COVID-19. Another statement from the Minister of Health regarding the spread of COVID-19 was redelivered where the Minister of Health reiterated that until 11 February 2020 Indonesia had no confirmed cases. ${ }^{17}$ In addition, the Minister of Health also offered a persuasion to pray in order to prevent the spread of COVID-19. ${ }^{18}$ But on the other

15 Feri Agus Setyawan, "Mahfud: RI Satu-satunya Negara Besar di Asia Tak Kena Corona", CNN Indonesia, 7 February 2020, retrieved 8 April 2020, https://www.cnnindonesia.com/nasion al/20200207194915-20-472750/mahfud-ri-satusatunya-negara-besar-di-asia-tak-kena-corona

16 Herdi Alif Al Hikam, "Canda Luhut saat Ditanya Corona Masuk Batam: Mobil?", Detik. com, 10 February 2020, retrieved 8 April 2020, https://finance.detik.com/berita-ekonomibisnis/d-4893152/canda-luhut-saat-ditanya-coronamasuk-batam-mobil

17 Kompas.com, "Menkes: Belum Ada Virus Corona Terdeteksi Harusnya Besyukur, Bukan Dipertanyakan", Kompas, 11 February 2020, retrieved 8 April 2020, https://nasional.kompas. com/read/2020/02/11/16255511/menkes-belum-adavirus-corona-terdeteksi-harusnya-bersyukur-bukan

18 Andhika Prasetia, "Doakan Indonesia Bebas Corona, Menkes: Kenapa Malu Andalkan Tuhan?", Detik.com, 17 February 2020, retrieved 8 April 2020, https:// news.detik.com/berita/d-4902550/doakan-indonesiabebas-corona-menkes-kenapa-malu-andalkan-tuhan 
hand, the Minister of Health also gave a statement related to Indonesia's readiness in dealing with the spread of COVID-19, such as the availability of detection devices. ${ }^{19}$

Other statements are still made by highlevel officials, such as a statement from the Minister of Transportation which states that the Indonesian people will not be infected with COVID-19 because they consume "nasi kucing". ${ }^{20}$ Likewise, the statement given by the Vice President which links to the "Do'a Qunut" for there have not been confirmed cases. ${ }^{21}$ In addition to the statement, the Government issued a policy on the impact of the spread of COVID-19, which is a budget of 72 billion in the tourism aspect. ${ }^{22}$

It can be concluded from the statement and even the policy of the Indonesian Government on the response of the spread of COVID-19 that the government tried to construct the issue of the spread of COVID-19 merely as a health issue. That means, from this situation the government carried out desecuritization on the issue of the spread of COVID-19. That means, the government has not focused on the spread of COVID-19 as a security issue that can threaten the existence of the state.

19 Kompas, "Kronologi dan Urutan Munculnya 6 Orang Positif Virus Corona di Indonesia", Kompas, 9 March 2020, retrieved 23 August 2020, https://nasional. kompas.com/read/2020/03/09/05280011/kronologidan-urutan-munculnya-6-orang-positif-viruscorona-di-indonesia?page $=$ all

20 Andri Saubani, "Kelakar Menhub: Kita Kebal Corona karena Doyan Nasi Kucing", Republika, 24 February 2020, retrieved 8 April 2020, https://republika.co.id/ share/q5ul4k409

21 Rendy Ferdiansyah, "Wapres: Indonesia Negatif Korona Berkat Doa Ulama", Republika, 27 February 2020, retrieved 8 April 2020, https://republika.co.id/ share/q5ul4k409

22 CNN Indonesia, "Wishnutama Rinci Dana Rp72 $M$ buat Wisata, Termasuk Influencer", CNN Indonesia, 26 February 2020, retrieved 8 April 2020, https://www.cnnindonesia.com/ekono mi/20200226174101-532-478425/wishnutamarinci-dana-rp72-m-buat-wisata-termasuk-influencer
The situation formed by the response of the Indonesian Government to the spread of COVID-19 to change when the Indonesian Government gave confirmation of the COVID-19 case in Indonesia on March 2, 2020. ${ }^{23}$ Until finally it was reported that WHO sent a letter to President Joko Widodo that Indonesia should follow the steps to prevent the spread of COVID-19 from $\mathrm{WHO}$ and asked Indonesia to establish an emergency response to the spread of covid $-19 .{ }^{24}$

Initially the Indonesian Government showed actions that positioned the issue of the spread of COVID-19 only as a health issue. But then it can be said that the actions of the Indonesian Government to construct the health issue into a security issue. The first action by the Indonesian Government was to issue Presidential Decree number 7 of 2020 concerning the Task Force for the Acceleration of Handling COVID-19. This is in accordance with statements from President Spokesman Fadjroel Rachman, as follows;

"Most of the recommendations in the letter have been carried out by the Indonesian Government during the COVID-19 outbreak. The government has improved its handling by issuing Presidential Decree No. 7/2020 concerning the Task Force for the Acceleration of Handling COVID-19 to sharpen the government's coordination skills." ${ }^{25}$

23 Taylor Derrick Bryson, "A Timeline of the Coronavirus Pandemic”, New York Times, 7 April 2020, retrieved 9 April 2020, https://www.nytimes.com/article/ coronavirus-timeline.html

24 Gorbiano Marchio Irfan, "Indonesia's first two confirmed COVID-19 cases", The Jakarta Post 2 March 2020, retrieved 9 April 2020, https://www.thejakartapost. com/news/2020/03/02/breaking-jokowi-announcesindonesias-first-two-confirmed-COVID-19-cases.html

25 Rolando Fransiscus Sihombing, "Rapat di DPR, Ribka Tjiptaning Bercanda Korona 'Komonitas Rondo Mempesono", Detik.com, 3 February 2020, retrieved 8 April 2020, https://news.detik.com/ berita/d-4883599/rapat-di-dpr-ribka-tjiptaningbercanda-korona-komunitas-rondo-mempesona 
The policy taken by the Indonesian Government is a turning point for positioning the issue of the spread of COVID-19 on securitization. In addition to the change in position, it is called a turning point because it is the first action from the government that leads to securitization in the issue of the spread of COVID-19 which is a measurement point for further action from the aligned government.

Other actions that lead to securitization such as statements made by representatives of the National Disaster Management Agency, as follows;

“... so that BNPB (Disaster Management National agency) needs to extend the (emergency status) again from February 29 to May 29, 2020 ..”26

The policy shows that the Indonesian Government has firmly positioned the issue of the spread of COVID-19 as a security issue. This is because the policies issued by the government to handle the spread of COVID-19 in Indonesia take into consideration the situation that is increasingly threatening to the Indonesian people as seen from the increasing number of COVID-19 cases. The Indonesian people, which is the referent object in the spread of COVID-19, is one of the components in positioning an issue as a security issue.

In addition to the policy of establishing a Gugus Tugas Percepatan Penanganan COVID-19 through the issuance of a Presidential Decree, the Indonesian Government is also taking other actions in dealing with the spread of COVID-19. This action is to transfer the Wisma Atlet as an emergency hospital for handling COVID-19

26 Tim detikcom, "Pernyataan Terbaru Pemerintah soal Penanganan Corona 17 Maret 2020", Detik.com, 17 March 2020, retrieved 10 April 2020, https:// news.detik.com/berita/d-4942939/pernyataanterbaru-pemerintah-soal-penanganan-corona-17maret-2020/5 patients. ${ }^{27}$ This was done on the basis that the Indonesian Government saw the spread of COVID-19 as something that needed to be taken seriously because it involved the safety of all Indonesian citizens, which would also have an impact on the existence of Indonesia itself. Therefore, with the use of the Wisma Atlet, at least the Indonesian Government will find it easier to control the spread of COVID-19. This policy is also in line with the designation of many hospitals in Indonesia as referral hospitals (Rumah Sakit Rujukan) for COVID-19 patients.

The government also issued a circular from the Ministry of Internal Affairs regarding the formation of a Gugus Tugas Percepatan Penanganan COVID-19 in the Regions. ${ }^{28}$ As previously explained, handling the spread of COVID-19 is not only carried out by the central government but also at the local government level. Considering that all Indonesian people are referent objects which are objects that are threatened by the spread of COVID-19, therefore handling must be done thoroughly to the lowest level of government. Until the Indonesian Government, through the approval of the Ministry of Health, approved the implementation of Pembatasan Sosial Berskala Besar (PSBB) in the Jakarta Province, which was then followed by areas around Jakarta in implementing the PSBB such as Bandung, Bogor and its

27 Yopi Makdori, "RS Darurat COVID-19 di Wisma Atlet Siap Beroperasi Senin 23 Maret 2020", Liputan6. com, 22 March 2020,retrieved 10 April 2020, https://www.liputan6.com/news/read/4208427/rsdarurat-COVID-19-di-wisma-atlet-siap-beroperasisenin-23-maret-2020

28 Farih Maulana Sidik, "Mendagri Terbitkan Surat Edaran, PemdaDapat Tetapkan Darurat Corona", Detik.com, 30 March 2020, retrieved 10 April 2020, https://news.detik.com/berita/d-4957763/mendagriterbitkan-surat-edaran-pemda-dapat-tetapkandarurat-corona 
surroundings. ${ }^{29}$ This policy reiterates that the Indonesian Government positions the issue of the spread of COVID-19 as a security issue. It can be concluded that the actions of the Indonesian Government have focused on handling the overall spread of COVID-19 in Indonesia.

Apart from being seen from a number of these policies, Indonesia's seriousness in overcoming the spread of COVID-19 which makes this health issue a security issue can be seen from other policies issued by the Indonesian Government. In the January to March 2020 period itself, Indonesia has issued several policies in dealing with the spread of COVID-19. Some of these policies are Decision of Minister of Health No: HK.01.07 / MENKES / 104/2020, Decision of Head of BNPB 9A / 2020, Presidential Decree 9/2020, Decision of Minister of Finance 6/KM.7 / 2020, Decision of Minister of Health HK.01.07 / MENKES / 182/2020, Minister of Finance Regulation No: 19 / PMK.07 / 2020, Chief of the Indonesian National Police Mandate No. MAK / 2 / III / 2020, Presidential Decree 9/2020, President Instruction 4/2020, Minister of Finance Regulation No: 23 / PMK.03 / 2020, Circulated letter SE 2/2020, Circulated letter SE 8/2020, Government Regulation in Lieu of Law No. 1/2020, Presidential Decree No. 11/2020, and Government Regulation No. 21/2020. ${ }^{30}$ In a span of approximately three months, the Indonesian Government has issued several policies to deal with the spread ofCOVID-19. This shows that the seriousness

29 Rakhmat Nur Hakim, "Disetujui Menkes, PSBB DKI Jakarta Mulai Berlaku Selasa 7 April 2020", Kompas. com, 7 April 2020, retrieved 10 April 2020, https:// nasional.kompas.com/read/2020/04/07/11582841/ disetujui-menkes-psbb-dki-jakarta-mulai-berlakuselasa-7-april-2020

30 Riyanti Djalante, "Review and analysis of current responses to COVID-19 in Indonesia: Period of January to March 2020," Progress in Disaster Science, Volume 6 (4 April 2020). of every element in the government is taking part in the spread of COVID-19 in Indonesia.

Decision of Minister of Health No: HK.01.07 / MENKES / 104/2020 stipulates that COVID-19 infection is a disease that can cause an epidemic and in this regulation describes the efforts to overcome the spread of COVID-19 carried out by the Indonesian Government. The prevention efforts undertaken by the Minister of Health include providing information and education to the Indonesian people regarding the prevention of the spread of COVID-19, taking swift steps in the spread of COVID-19, providing health services, and coordinating across sectors. $^{31}$ In addition to the Minister of Health, the Minister of Finance also issued a regulation such as the Decision of Minister of Finance 6 / KM.7 / 2020 which regulates the distribution of funds specifically allocated for operational funds in preventing the spread of COVID-19. ${ }^{32}$ Not only did the president or minister issue a regulation in handling the spread of COVID-19, but also the police also issued a regulation to prevent the spread of COVID-19. The regulation is the Chief of Police of the Republic of Indonesia Mandate No. MAK / 2 / III / 2020. In the mandate, it is stated that there is a prohibition against gathering in large numbers, either in public places or in one's own surroundings. ${ }^{33}$ This was done to reduce the possibility of an increase in the number of COVID-19 cases, given WHO recommendations to maintain distance from other people so that transmission rates are low. With the participation of the police, this

31 Riyanti Djalante, "Review and analysis of current responses to COVID-19 in Indonesia: Period of January to March 2020," Progress in Disaster Science, Volume 6 (4 April 2020).

32 Menteri Keuangan Republik Indonesia, "Keputusan Menteri Keuangan Republik Indonesia Nomor 6/ KM.7/2020 Tahun 2020, retrieved 23 August 2020.

33 Kepala Kepolisian Republik Indonesia, "Maklumat Kepala Kepolisian Negara Republik Indonesia Nomor: Mak/2/II/2020, retrieved 23 August 2020. 
strengthens the argument that the spread of COVID-19 has become a threat to all Indonesian people.

Given that COVID-19 is a global pandemic, which means that all countries in the world are affected by the spread of COVID-19. It can be said that the spread of COVID-19 crosses national borders which is why cooperation between countries in the world is needed. This is done so that the recommendation of $\mathrm{GHG}$ which in this case is $\mathrm{WHO}$ is implemented properly, so that the handling of COVID-19 can be carried out optimally at the international, country, or regional level of each country.

This situation requires the Ministry of Foreign Affairs of Indonesia to take part in handling the spread of COVID-19. This participation is through the procurement of cooperation between Indonesia and other countries in the context of handling the spread of COVID-19. As on February 20, 2020, Indonesia together with other countries that are members of the Association of Southeast Asian Nations (ASEAN) held a Special Meeting of the Ministers of Foreign Affairs of ASEAN and People's Republic of China (PRC) in Vientiane, Laos. The meeting focused on discussing the outbreak of COVID-19. During the meeting, it was mentioned several suggestions from Indonesia in handling COVID-19, namely coordination between ASEAN member countries and the PRC, strengthening mechanisms for handling COVID-19, strengthening communication, and supporting cooperation in vaccine production..$^{34}$ Through this meeting it will

34 Ministry of Foreign Affairs of the Republic Indonesia, "Minister of Foreign Affairs Retno invites ASEAN and PRC to Strengthen Regional Mechanism to Cope with COVID-19 Outbreak", Kemlu.go.id, 20 February 2020, retrieved 23 August 2020, https://kemlu.go.id/ portal/en/read/1065/berita/minister-of-foreign-affairsretno-invites-asean-and-prc-to-strengthen-regionalmechanism-to-cope-with-covid-19-outbreak also strengthen Indonesia in dealing with the spread of COVID-19, considering that members of the meeting have experience in dealing with the SARS outbreak in 2003. In addition to collaborating with other parties such as ASEAN and PRC, the Ministry of Foreign Affairs also issued policies related to entry restrictions. for foreign nationals. Details of the policy stated that travelers from Iran, Italy and South Korea are prohibited from entering Indonesia or transiting in Indonesia, enacting a health certificate for travelers from the three countries, enforcing a Health Alert Card, and conducting additional health checks at the airport of arrival. ${ }^{35}$ Given that COVID-19 is a global pandemic - as previously mentioned - therefore restrictions between countries are needed so that the rate of community displacement can be controlled by the government and controlled interactions with foreign citizens, which hopefully will reduce the level of the spread of COVID-19. Through the Ministry of Foreign Affairs, the Indonesian Government also undertakes bilateral cooperation such as the cooperation between the Indonesian Government and the Japanese Government. The collaboration was carried out for the acquisition of the Avigan drug, which is a drug to treat influenza patients which is also thought to be effective in relieving the symptoms of COVID-19. ${ }^{36}$

35 Kementerian Luar Negeri Republik Indonesia, "Kebijakan Pemerintah Indonesia Terkait Perkembangan COVID-19", Kemlu.go.id, 5 March 2020, retrieved 23 August 2020, https://kemlu.go.id/ portal/id/read/1104/berita/kebijakan-pemerintahindonesia-terkait-perkembangan-covid-19

36 Ministry of Foreign Affairs of the Republic Indonesia, "The Japanese Government Delivered 12,200 Avigan Tablets for Treatment of COVID-19 in Indonesia", Kemlu.go.id,19 May 2020, retrieved 23 August 2020, https://kemlu.go.id/portal/en/read/1313/ berita/the-japanese-government-delivered-12200. avigan-tablets-for-treatment-of-covid-19-inindonesia 
When viewed from the participation of every element of government in handling the spread of COVID-19, it can be seen that there is a harmonization formed by the implementation of a GHG framework, which in this case is WHO. The implementation of the Indonesian Government's recommendation from WHO was a turning point which later changed the Indonesian Government's attitude in dealing with the spread of COVID-19 which has become a global pandemic. It is this global pandemic that requires the Indonesian Government not only to focus on implementation at domestic level but also overseas, which in turn will have an impact on the safety of Indonesian citizens. Therefore, harmonization between countries is needed to strengthen agility in handling the spread of COVID-19. Through policies issued by the Indonesian Government with harmonization between government elements and between other countries, it can be seen that COVID-19, which was originally only a health issue, has turned into a security issue.

\section{Audience}

Audience is the target of the speech act carried out by securitizing actors. This component also provides approval for actions taken by securitizing actors in the decision making process of an issue. Then the final result formed is justification for the actions of securitizing actors that an issue becomes a security issue based on the presence of a party that is threatened.

In the issue of the spread of COVID-19 in Indonesia, Indonesian society as a whole was identified as an audience. This can be seen from the policy of establishing the Task Force for the Acceleration of Handling COVID-19 as a turning point showing that the policy was made on the basis of the protection provided by the government to the Indonesia society as a whole. This then forms the justification that the spread of COVID-19 is dangerous which requires the Indonesian people to pay more attention to the direction of the government. Other justifications can also be seen from society's responses to the submission of several regions such as Bogor, Bekasi, and Depok to apply for Large-Scale Social Restrictions enactments which are then approved by the government through the Ministry of Health. Most of the Indonesian people responded well to the implementation of the PSBB. This can be seen from a survey conducted by several institutions which showed that the majority of the society agreed with the implementation of the PSBB with a percentage reaching $87.6 \%{ }^{37}$ In addition, there is another survey which states that $39 \%$ of Indonesian people agree to impose sanctions on parties who do not follow the PSBB regulations. ${ }^{38}$ In addition to a survey that shows the Indonesian people agree with the implementation of the PSBB, society compliance with the PSBB enforcement rules such as wearing masks, and the application of physical distancing both on public and private vehicles ${ }^{39}$ are

37 Yogi Ernes, "Survei SMRC: 87,6\% Masyarakat RI Setuju PSBB untuk Cegah Penularan Corona", Detik. com, 17 April 2020, retrieved 23 September 2020, https://news.detik.com/berita/d-4980790/surveismrc-876-masyarakat-ri-setuju-psbb-untuk-cegahpenularan-corona

38 Fitria Chusna Farisa, "Survei SMRC: 39 Persen Masyarakat Indonesia Setuju Sanksi bagi Pelanggar PSBB", Nasional Kompas, 17 April 2020, retrieved 23 September 2020, https:/nasional.kompas.com/ $\mathrm{read} / 2020 / 04 / 17 / 11221731 /$ survei-smrc-39-persenmasyarakat-indonesia-setuju-sanksi-bagi-pelanggarpsbb?page $=$ all

39 Bonfiliio Mahendra Wahanaputra Ladjar, "Kapolda Nana Sudjana Sebut Masyarakat Kian Patuhi Aturan PSBB", Kompas, 13 April 2020, retrieved 23 September 2020, https://megapolitan.kompas.com/ read/2020/04/13/13453861/kapolda-nana-sudjanasebut-masyarakat-kian-patuhi-aturan-psbb 
important points in approval as an audience for the spread of COVID-19.

\section{WHO as Global Health Governance}

The WHO appeal is a pressure for the follow-up handling of the spread of COVID-19 Indonesia. In this issue of the spread of COVID-19, WHO has a role as a $\mathrm{GHG}^{40}$ which gives the appeal that shows the norms established by WHO for handling the spread of COVID-19. Therefore Indonesia, as a WHO member, requires following the appeal of WHO. It can be said that the change in action from the Indonesian Government on the spread of COVID-19, one of which was influenced by the pressure from $\mathrm{GHG}$, where global governance is an appeal from WHO. In the end, the change led to the Indonesian Government's actions to make the spread of COVID-19 which was initially a health issue positioned as a security issue. The framing that issue as a security issue emphasizes minimizing the spread of COVID-19 which is the role of GHG in disease control and epidemic control. ${ }^{41}$ This role is carried out by $\mathrm{WHO}$ as a stabilization for handling the spread of COVID-19. From that situation, it can be seen that the GHG formed by WHO on handling COVID-19 is monocentricity. It can be said that because WHO has a great influence on the spread of COVID-19, even it can be said to be a major force at the global level which is also able to influence at the country level, ${ }^{42}$ which in this case is Indonesia.

40 Kelley Lee and Adam Kamradt-Scott, "The multiple meanings of global health governance: a call for conceptual clarity," Global Health 10 (April 2014): 28.

41 Colin Mclnnes and Kelley Lee, "Health, Security, and Foreign Policy", Review of International Studies Vol. 32, No.1 (January 2006): 5-23.

42 Rakhyun E Kim, "Is Global Governance Fragmented, Polycentric, or Complex? The State of the Art of the Network Approach", International Studies Review (18 September 2019).

\section{Conclusion}

Statements delivered by several high-level officials position the spread of COVID-19 only as a health issue. However, the Indonesian Government's actions changed when there was a GHG institution, WHO, which appealed for handling COVID-19 in Indonesia. It can be said that the appeal is a norm that is formed where Indonesia must implement the appeal from WHO. That obligation to comply is a form of "pressure" given by WHO. From the appeal, the Indonesian Government issued Presidential Decree number 7 of 2020 concerning the Task Force for the Acceleration of Handling COVID-19. This is a "turning point" for the government's actions towards handling the spread of COVID-19 in Indonesia. These changes lead to the position of the spread of COVID-19 issue as a security issue in the Indonesian society as a referent object because it is a party to be existentially threatened. Until finally a justification was formed from the Indonesian society who were also the audience of the speech act of securitizing actors that the spread of COVID-19 would endanger the Indonesian society as a whole which required the public to pay more attention to government directives. In addition to the formation of that justification, the Indonesian society are also an important object in overcoming the spread of COVID-19 in Indonesia where the level of discipline of the Indonesian society is a determinant of the success of the direction of the Indonesian Government on the issue of the spread of COVID-19 as a security issue. 


\section{REFERENCES}

Al Hikam, Herdi Alif, "Canda Luhut saat Ditanya Corona Masuk Batam: Mobil?", Detik.com, 10 February 2020, retrieved 8 April 2020, https://finance.detik. com/berita-ekonomi-bisnis/d-4893152/ canda-luhut-saat-ditanya-coronamasuk-batam-mobil

Ariefana, Pebriansyah, "Jokowi Pastikan Indonesia Aman dari Corona", Suara. com, 27 Januay 2020, retrieved 8 April 2020, https:/www.suara.com/ news/2020/01/27/123913/jokowipastikan-indonesia-aman-dari-viruscorona

Bryson, Taylor Derrick, "A Timeline of the Coronavirus Pandemic", 7 April 2020, retrieved April 9, 2020, NY Times: https://www.nytimes.com/article/ coronavirus-timeline.html

Buzan, Barry, Ole Wæver, Jaap de Wilde, A New Framework For Analysis (London: Lynne Rienner Publisher), 1998.

CNN Indonesia, "Ditanya WHO Soal Tanggap Darurat, Jokowi Jawab dengan Keppres", 14 March 2020, retrieved April 9, 2020, CNN Indonesia: https://www.cnnindonesia.com/nas ional/20200314080137-20-483342/ ditanya-who-soal-tanggap-daruratjokowi-jawab-dengan-keppres

CNN Indonesia, "Wishnutama Rinci Dana Rp72 M buat Wisata, Termasuk Influencer", CNN Indonesia, 26 February 2020, retrieved 8 April 2020, https://www.cnnindonesia.com/ekon omi/20200226174101-532-478425/ wishnutama-rinci-dana-rp72-m-buatwisata-termasuk-influencer
Ernes, Yogi, "Survei SMRC: 87,6\% Masyarakat RI Setuju PSBB untuk Cegah Penularan Corona", Detik. com, 17 April 2020, retrieved 23 September 2020, https://news.detik. com/berita/d-4980790/survei-smrc876-masyarakat-ri-setuju-psbb-untukcegah-penularan-corona

Farisa, Fitria Chusna, "Survei SMRC: 39 Persen Masyarakat Indonesia Setuju Sanksi bagi Pelanggar PSBB", Nasional Kompas, 17 April 2020, retrieved 23 September 2020, https://nasional.kompas. $\mathrm{com} / \mathrm{read} / 2020 / 04 / 17 / 11221731 /$ survei-smrc-39-persen-masyarakatindonesia-setuju-sanksi-bagi-pelanggarpsbb? page $=$ all

Ferdiansyah, Rendy, "Wapres: Indonesia Negatif Korona Berkat Doa Ulama", Republika, 27 February 2020, retrieved 8 April 2020, https://republika.co.id/ share/q5ul4k409

Hakim, Rakhmat Nur, "Disetujui Menkes, PSBB DKI Jakarta Mulai Berlaku Selasa 7 April 2020", Kompas.com, 7 April 2020, retrieved 10 April 2020, https://nasional.kompas.com/ $\mathrm{read} / 2020 / 04 / 07 / 11582841 /$ disetujuimenkes-psbb-dki-jakarta-mulaiberlaku-selasa-7-april-2020

Held, David, "Elements of A Theory Of Global Governance," SAGE Journals Volume 42 Issue 9 (November 2016): 837-846.

Irfan, Gorbiano Marchio, "Indonesia's first two confirmed COVID-19 cases", 2 March 2020, retrieved April9, 2020, The Jakarta Post: https://www.thejakartapost.com/ news/2020/03/02/breaking-jokowiannounces-indonesias-first-twoconfirmed-COVID-19-cases.html 
Kementerian Luar Negeri Republik Indonesia, "Kebijakan Pemerintah Indonesia Terkait Perkembangan COVID-19", 5 March 2020, retrieved August 23, 2020, https:// kemlu.go.id/portal/id/read/1104/berita/ kebijakan-pemerintah-indonesia-terkaitperkembangan-covid-19

Kepala Kepolisian Republik Indonesia, "Maklumat Kepala Kepolisian Negara Republik Indonesia Nomor: Mak/2/ III/2020, retrieved August 23, 2020.

Kim, Rakhyun E, "Is Global Governance Fragmented, Polycentric, or Complex? The State of the Art of the Network Approach", International Studies Review (18 September 2019).

Kompas, "Kronologi dan Urutan Munculnya 6 Orang Positif Virus Corona di Indonesia", 9 March 2020, retrieved August 23, 2020, Kompas: https:/nasional.kompas.com/ $\mathrm{read} / 2020 / 03 / 09 / 05280011 / \mathrm{kronologi}$ dan-urutan-munculnya-6-orang-positifvirus-corona-di-indonesia? page $=$ all

Kompas.com, "Menkes: Belum Ada Virus Corona Terdeteksi Harusnya Besyukur, Bukan Dipertanyakan", Kompas, 11 February 2020, retrieved 8 April 2020, https://nasional. kompas.com/read/2020/02/11/16255511/ menkes-belum-ada-virus-coronaterdeteksi-harusnya-bersyukur-bukan

Ladjar, Bonfiliio Mahendra Wahanaputra, "Kapolda Nana Sudjana Sebut Masyarakat Kian Patuhi Aturan PSBB”, Kompas, 13 April 2020, retrieved 23 September 2020, https://megapolitan.kompas.com/ $\mathrm{read} / 2020 / 04 / 13 / 13453861 /$ kapoldanana-sudjana-sebut-masyarakat-kianpatuhi-aturan-psbb

Lee, Kelley; and Kamradt-Scott, Adam, "The multiple meanings of global health governance: a call for conceptual clarity," Global Health 10 (April 2014): 28.
Makdori, Yopi, "RS Darurat COVID-19 di Wisma Atlet Siap Beroperasi Senin 23 Maret 2020", Liputan6.com, 22 March 2020,retrieved 10 April 2020, https:// www.liputan6.com/news/read/4208427/ rs-darurat-COVID-19-di-wisma-atletsiap-beroperasi-senin-23-maret-2020

Maulana, Hadi, "Menkes Terawan: 1 WNI Terpapar Virus Corona, Biar Pemerintah Singapura yang Menanganinya", Kompas, 5 February 2020, retrieved 8 April 2020, https://regional.kompas.com/ $\mathrm{read} / 2020 / 02 / 05 / 20124591 /$ menkesterawan-1-wni-terpapar-virus-coronabiar-pemerintah-singapura-yang

Mclnnes, Colin and Kelley Lee, "Health, Security, and Foreign Policy", Review of International Studies Vol. 32, No.1 (January 2006): 5-23.

Menteri Keuangan Republik Indonesia, "Keputusan Menteri Keuangan Republik Indonesia Nomor 6/KM.7/2020 Tahun 2020, retrieved August 23, 2020.

Ministry of Foreign Affairs of the Republic Indonesia, "Minister of Foreign Affairs Retno invites ASEAN and PRC to Strengthen Regional Mechanism to Cope with COVID-19 Outbreak", Kemlu. go.id, 20 February 2020, retrieved 23 August 2020, https://kemlu.go.id/ portal/en/read/1065/berita/minister-offoreign-affairs-retno-invites-asean-andprc-to-strengthen-regional-mechanismto-cope-with-covid-19-outbreak

Ministry of Foreign Affairs of the Republic Indonesia, "The Japanese Government Delivered 12,200 Avigan Tablets for Treatment of COVID-19 in Indonesia", 19 May 2020, retrieved August 23, 2020, https:/kemlu.go.id/portal/en/read/1313/ berita/the-japanese-governmentdelivered-12200-avigan-tablets-fortreatment-of-covid-19-in-indonesia 
Prasetia, Andhika, "Doakan Indonesia Bebas Corona, Menkes: Kenapa Malu Andalkan Tuhan?", Detik.com, 17 February 2020, retrieved 8 April 2020, https://news. detik.com/berita/d-4902550/doakanindonesia-bebas-corona-menkes-kenapamalu-andalkan-tuhan

Saubani, Andri, "Kelakar Menhub: Kita Kebal Corona karena Doyan Nasi Kucing", Republika, 24 February 2020, retrieved 8 April 2020, https://republika.co.id/ share/q5ul4k409

Setyawan, Feri Agus, "Mahfud: RI Satusatunya Negara Besar di Asia Tak Kena Corona", CNN Indonesia, 7 February 2020, retrieved 8 April 2020, https://www.cnnindonesia.com/nas ional/20200207194915-20-472750/ mahfud-ri-satu-satunya-negara-besardi-asia-tak-kena-corona

Sidik, Farih Maulana, "Mendagri Terbitkan Surat Edaran, PemdaDapat Tetapkan Darurat Corona", Detik.com, 30 March 2020, retrieved 10 April 2020, https:// news.detik.com/berita/d-4957763/ mendagri-terbitkan-surat-edaranpemda-dapat-tetapkan-darurat-corona

Sihombing, Rolando Fransiscus, "Rapat di DPR, Ribka Tjiptaning Bercanda Korona 'Komonitas Rondo Mempesono", Detik. com, 3 February 2020, retrieved 8 April 2020, https://news.detik.com/ berita/d-4883599/rapat-di-dpr-ribkatjiptaning-bercanda-korona-komunitasrondo-mempesona
Tim detikcom, "Pernyataan Terbaru Pemerintah soal Penanganan Corona 17 Maret 2020", Detik.com, 17 March 2020, retrieved 10 April 2020, https:// news.detik.com/berita/d-4942939/ pernyataan-terbaru-pemerintah-soalpenanganan-corona-17-maret-2020/5

World Health Organization, "Advice for the public", retrieved August 23, 2020, https://www.who.int/emergencies/ diseases/novel-coronavirus-2019/ advice-for-public

World Health Organization, "Coronavirus", retrieved April 9, 2020, https:// www.who.int/health-topics/ coronavirus\# tab=tab_1

World Health Organization, "Coronavirus disease (COVID-19) Pandemic", retrieved April 9, 2020, https://www. who.int/emergencies/diseases/novelcoronavirus-2019 